\title{
A Study on the Longitudinal Relation Between Maternal Parenting Stress, Warmth Parenting, and Children's Aggressive Behavior Using Autoregressive Cross-Lagged Modeling : a Multigroup Analysis Across Income Levels
}

Taehee Youn $^{1}$

Ph. D. Student, Department of Social Innovation Convergence Program, Sungkyunkwan University, Seoul, Korea ${ }^{1}$

\author{
소득수준에 따른 어머니의 양육스트레스, 온정적 양육행동, \\ 유아의 공격적 행동 간의 자기회귀 교차지연 효과 검증 \\ 윤태희 ${ }^{1}$ \\ 성균관대학교 소셜이노베이션융합전공 박사과정생 ${ }^{1}$
}

Objectives: This study aimed to analyze the longitudinal relationship between maternal parenting stress (MPS), warmth parenting (WP), and children's aggressive behavior (CAB) in early childhood across income levels.

Methods: An autoregressive cross-lagged model was used to assess the mothers and children of 723 families from the Panel Study on Korean Children across the sixth (age 5), seventh (age 6), and eighth (age 7) waves, and bootstrapping was conducted to examine the mediation effects. Further, a multigroup analysis was performed to assess the model's hypothesized relationships for the low-income and middle-income groups. IBM AMOS 23.0 and SPSS Statistics 26 were used to analyze the data.

Results: The results are summarized as follows: First, MPS, WP, and CABs remained unchanged over time. Second, MPS had a significantly negative impact on later WP, and WP negatively affected later MPS. Third, prior WP had a significantly negative impact on CAB. Furthermore, the relationship between MPS and CAB was mediated by WP. Lastly, during the study period, the multi-group analysis found no significant differences in the autoregressive cross-lagged model between the two income groups (the low-income and middle-income groups).

Conclusion: The findings revealed that MPS reduced WP, which exacerbated CAB. By illustrating the link between MPS, WP, and CAB, it was highlighted that educational interventions for mothers to minimize parenting stress are likely to have a positive influence on children's aggressive behavior. More implications are also discussed as a result of these findings.

Keywords: parenting stress, warmth parenting, aggressive behavior, autoregressive cross-lagged, income

Corresponding Author: Taehee Youn, Ph. D. Student, Department of Social Innovation Convergence Program, Sungkyunkwan University, 25-2, Sungkyunkwan-ro, Jongno-gu, Seoul, Korea

E-mail: smileyth@g.skku.edu (c) The Korean Association of Child Studies

This is an Open Access article distributed under the terms of the Creative Commons Attribution Non-Commercial License (http:// creativecommons.org/licenses/by-nc/4.0) which permits unrestricted noncommercial use, distribution, and reproduction in any medium, provided the original work is properly cited. 


\section{Introduction}

우리는 하루라는 시간 동안 헤아릴 수 없이 많은 사람과 관계 를 갖고 살아간다. 어떤 이는 타인과 조화로운 관계를 맺고 살 아가지만, 어떤 이는 관계에서 생긴 갈등을 공격적인 행동으 로 해결하여 사회적 문제를 안고 살아가기도 한다. 공격행동 은 사회적 존재인 인간에게 매우 중요한 문제로 여겨지기 때문 에, 공격성에 관해서 오랜 연구들이 진행된 바 있다. 공격행동 은 위협이나 해가 될 수 있는 행동으로 언어적 혹은 신체적인 방법으로 표현될 수 있다(Fitzpatrick, Srivorakiat, Wink, Pedapati \& Erickson, 2016). Tremblay (2004)의 연구에 따르면, 공격적 행 동에 중요한 시기는 다름 아닌 유아기이다. 이 시기는 유아가 공격행동을 배우게 되고 그 행동을 계속적으로 유지하게 되는 결정적인 시기로, 공격행동을 보인 유아가 부모로부터 적절한 대처와 온정적인 양육방식으로 양육되지 못할 때 만성적인 공 격행동을 보인다고 설명되었다. 유아를 대상으로 실시한 종단 연구(Dodge et al., 2003)에서는 초등학교 1학년 시기에 공격성 이 높은 유아일수록 또래로부터 부정적인 평가와 거절을 자주 경험하고, 이러한 부정적 평가와 공격성에 대한 보고는 초등 학교 고학년이 될 때까지 종단적으로 유지됨이 밝혀졌다. 이처 럼, 유아기에 높은 공격성을 보인 아동은 13-18세 청소년기에 더 높은 수준의 폭력적 활동과 반항적인 행동을 보였고, 청소 년기에 더욱 확고하게 자리 잡은 공격행동은 이후 성인까지 이 어져 심각한 반사회적 행동이나 범죄로 초래될 가능성이 높았 다(Bor, Najman, O'Callaghan, Williams, \& Anstey, 2001; Broidy et al., 2003; Salimi et al., 2019). 이렇듯, 다수의 선행연구를 통 해 전 생애에서 발현될 수 있는 공격행동을 미리 예방하기 위 해서는 적절한 조기개입이 매우 필요함을 알 수 있다. 특히, 유 아기에서 학령기로 전환되는 초등학교 1학년 시기는 유아가 처음으로 낮선 다수의 또래 및 교사와 관계를 맺게 되고, 수업 과 규칙 중심의 교실 환경에 대한 제약을 경험하여, 새로운 환 경으로 인한 많은 스트레스를 경험하는 때이다(Jeong \& Park, 2017). Huffman 등 (2001)에 따르면, 유아는 초등학교 1학년 때 처음으로 사회적으로 용인되고자 큰 노력을 하고, 역할 모델 을 구축하며, 다른 가치를 가진 타인과 조화를 만들어가기 시 작한다. 이 시기에 유아는 타인과의 상호작용을 통해 갈등을 해결하고자 자신의 감정을 표현하고, 자신 및 타인에 대한 이 해가 넓어지며, 타인과 원활하게 타협하는 행동을 형성하게 된 다. 그러나 이렇게 사회적 관계 형성 및 관계적 능력발달에 결 정적 시기인 초등 전환기에 나타나는 유아의 공격적 행동은 유 아가 관계를 형성하는데 위험요인이 되어, 이후 계속되는 관계
적, 인지적, 학업적 발달에 매우 부정적인 결과를 초래할 수 있 다. 따라서, 유아의 이후 발달을 위해 초등학교 입학 시기의 유 아의 공격행동에 관한 연구가 중요함을 알 수 있다.

초등입학 시기 유아의 반사회적이고 공격적인 행동은 입 학 전 어머니의 양육방식을 통해 형성되는 어머니와의 사회적 관계와 밀접한 관계가 있다(Huffman et al., 2001). 학교에 입학 하기 전 유아는 가장 많은 시간을 어머니와 보내며, 어머니와 의 상호작용을 통해 어머니가 사용하는 사회적 행동을 그대 로 모델링하게 된다(Ferreira et al., 2016). 이때, 부모에게 따뜻 한 양육방식으로 길러진 유아는 부모로부터 자신의 필요, 안 정감, 수용을 충분히 받게 되고, 이러한 상호작용방법을 그대 로 또래 관계에 적용함으로써 또래와 긍정적인 상호작용을 한 다(Georgiou, 2008). 반면, 부모로부터 매우 적대적이고 통제 적인 양육을 받은 유아는 본인이 학습한 부정적 상호작용방법 을 친구 관계에서 그대로 사용하여, 공격행동과 관계적 갈등 의 문제를 자주 일으키게 된다(Georgiou, 2008). 즉, 부모가 따 듯함 없이 규칙이나 순종만을 지나치게 강요하고 처벌적 양 육을 많이 사용할 때, 유아는 타인에 대한 낮은 이해와 위축 행동, 품행 장애, 높은 공격성을 보였다(Olson, Lopez-Duran, Lunkenheimer, Chang, \& Sameroff, 2011). 3세 유아를 대상으로 한 종단연구(Baydar \& Akcinar, 2017)에서 역시 혹독하고 처벌 적인 양육방식이 유아의 공격성 발달에 영향을 주었고, 유아 의 공격적 행동은 이후 부모의 양육방식에 영향을 미침을 보 여, 부모의 양육과 유아의 공격성 간에 양방향적 관계가 확인 되었다. 이는 부모의 양육이 자녀의 행동에 영향을 미칠 뿐 아 니라, 자녀의 행동 또한 부모의 양육에 영향을 미친다는 Wang 과 Liu (2018)의 설명을 통해 알 수 있다. 즉, 자녀는 부모의 혹 독한 양육으로 인해 공격성 및 혐오감을 갖게 되고, 이렇게 이 끌어진 자녀의 부정적 감정과 행동문제는 다시 부모가 화 또 는 적대적 감정을 갖도록 하여 자녀에게 처벌적 반응을 하게 되는 악순환이 반복될 수 있다(Granic \& Patterson, 2006). 이처 럼 어머니의 양육행동이 유아의 공격행동에 중요한 요인으로 작용한다는 선행연구 결과들을 바탕으로, 본 연구는 어머니의 양육행동에 영향을 미치는 변인들을 탐색하고 주요 변인들 간 의 관련성을 살펴봄으로써, 유아의 공격행동 증가를 예방하기 위한 대책 마련에 유익한 정보를 제공하고자 한다.

Anthony 등(2005)에 따르면, 학령 전환기 유아를 둔 부모에 게는 양육스트레스가 양육행동에 미치는 주요한 요인이었다. Abidin (1992)은 이를 양육스트레스가 양육행동을 통해 유아 의 공격행동에 이르는 매개모형으로 설명하였다. 양육스트레 스는 부모로서 갖추어야 하는 요구에 대한 부담으로(Abidin, 
1992), 부모 자신과 자녀에 대해 부정적인 감정을 갖는 데까 지 이를 수 있다(Gabler et al., 2018). 양육스트레스는 자녀를 양육하는 부모들이 모두 경험하게 되지만, 특별히 학령 전 시 기의 유아를 양육할 때 부모들은 양육에 필요한 많은 요구로 인해 높은 수준의 양육스트레스를 경험하게 된다(Anthony et al., 2005). 이때, 높은 수준의 양육스트레스는 부모가 양육에 서 발생하는 문제들을 효과적으로 대처하기 어렵도록 만든다 (Blasio, Camisasca, Miragoli, Ionio \& Milani, 2017). 양육스트레 스를 높은 수준으로 경험한 부모는 좌절, 분노, 두려움과 같이 자신의 부모 됨에 대한 부정적 정서로 인해 양육에 직면할 심 리적 유연성이 매우 떨어진 상태가 되고, 부모 역할을 수행해 야 하는 상황에서 자녀에게 덜 따뜻하고, 덜 민감하며, 통제 나 처벌을 많이 사용하는 권위주의적인 양육태도를 보이게 된 다(Burke \& Moore, 2015). 양육스트레스로 인해 통제와 권위 주의적 양육방식을 사용한 부모에게 양육받은 유아는 반사회 성/공격성, 자기중심적 폭발, 주의집중의 문제에서 유의하게 높은 수준을 보였다(Burke \& Moore, 2015). 또한, 높은 수준의 양육스트레스를 경험하는 어머니는 많은 짜증과 화를 표출하 였고(Prendergast \& MacPhee, 2020), 비록 이러한 부정적 감정 의 방향이 자녀에게 직접적으로 향하지 않더라도 부모로부터 화가 동반된 양육을 지속적으로 경험한 유아는 더 많은 문제 행동을 일으켰다(Cole, Michel, \& Teti, 1994). 이처럼 학령 전 환기 자녀를 둔 부모의 양육스트레스와 양육행동이 유아의 공 격성에 미치는 영향이 크다는 것을 예측할 수 있음에도 불구 하고, 어머니의 양육스트레스, 양육행동, 유아의 공격적 행동 간의 관련성에 대한 연구가 부족한 실정이다. 이 세 변인을 포 함한 연구는 있었지만, 연구대상의 연령이 유치원에 들어가기 전인 아주 어린 아동이나 청소년이고, 변인들 간의 인과적 관 계의 추론이 어려운 횡단연구들이었다. 따라서, 본 연구에서 는 어머니의 양육스트레스가 어머니의 온정적 양육행동 감소 를 매개로 유아의 공격적 행동에 이르는 매개경로를 설정하고 변인들 간의 관계를 살펴보고자 한다.

또한, 어린 시기 가정의 소득수준이 어머니의 스트레스, 양육행동, 유아의 행동적 문제와 관련이 있다는 선행연구들 (Dodge, Pettit, \& Bates, 1994; Granero, Louwaars, \& Ezpeleta, 2015)을 바탕으로, 본 연구에서는 변인들 간의 관계가 소득수 준에 따라 차이를 보이는지 확인하고자 한다. Dodge 등 (1994) 의 연구에서 소득수준이 낮은 아동일수록 혹독한 훈육을 더 많이 경험하였고, 가정 및 주변 환경에서 폭력성에 더 많이 노 출되었으며, 가정환경 내에서 인지적 자극을 덜 경험하였다. 뿐만 아니라, 소득수준이 낮은 어머니는 자녀에게 덜 온정적
이고, 가정에 대한 스트레스가 더 높고, 사회적 지지를 덜 받으 며, 더 많은 고립감을 느끼는 것으로 보고되었다. 소득수준이 낮은 가정의 아동은 이러한 위험 환경들을 매개로 높은 공격 성을 예측하였다. 하지만, 소득수준이 부모 및 자녀에게 미치 는 영향에 관한 연구의 결과가 다소 비일관적이었다. 낮은 소 득수준이 부모의 처벌적 양육행동을 통해 유아의 문제행동에 미치는 영향이 남아에게서는 나타나지만 여아에게는 나타나 지 않았던 연구결과(Granero et al., 2015)가 있었고, 부모의 학 대 및 방임이 아동의 공격성을 통해 행동문제에 미치는 영향 이 소득수준에 차이가 없었던 연구결과(Lim, 2015)가 있었다. 따라서, 본 연구에서는 소득수준에 따라 집단을 나누어 어머 니의 양육스트레스, 양육행동, 유아의 공격적 행동 간의 관계 에 차이를 보이는지 살펴보고자 한다.

더하여, 양육스트레스는 자녀가 발달함에 따라 누적되고 계속되기 때문에 유아에게 미치는 단기적 영향보다 장기적 영향에 관한 종단연구가 필요하다(Crnic, Gaze, \& Hoffman, 2005). 또한, 변인들 간의 구체적인 인과관계를 추론하기 위해 서는 반복측정을 기반한 종단자료의 사용이 논리적 설명을 가 능하게 하므로, 본 연구에서는 한국아동패널연구(Panel Study on Korean Children [PSKC])의 3차년도(6-8차) 종단자료를 사 용하였다. 특히 사회적 관계 형성에 결정적 시기인 초등학교 1 학년 시기 유아의 공격적 행동에 미치는 예측 변인들 간의 관 계를 살펴보고자, 어머니의 양육스트레스, 온정적 양육행동, 유아의 공격적 행동을 유아가 초등학교에 입학 하기 전인 만 5세와 6세, 그리고 초등학교에 입학한 만 7세 때 측정하여, 이 전 시점의 변인들이 이후 시점의 변인들에 어떠한 영향을 미 치는지 살펴보고자 한다. 보다 구체적으로, 세 변인들 간에 미 치는 영향이 시간의 경과에 따라 안정적인지 그리고 변인들 간에 인과적 관계가 있는지를 살펴봄으로써, 학령 전환기 유 아의 공격성에 대한 조기개입에 도움이 될 수 있는 정보를 제 공하고자 한다. 본 연구의 연구문제는 다음과 같다.

\section{연구문제 1}

어머니의 양육스트레스, 온정적 양육행동, 유아의 공격적 행 동은 시간의 경과에 따라 안정적으로 유지되며, 소득수준에 따른 차이가 존재하는가?

\section{연구문제 2}

어머니의 양육스트레스, 온정적 양육행동, 유아의 공격적 행 동 간의 인과관계가 시간의 경과에 따라 어떻게 나타나며, 소 득수준에 따른 차이가 존재하는가? 


\section{Methods}

\section{연구대상}

본 연구는 유아정책연구소에서 실시한 한국아동패널연구 (PSKC) 만 5세부터 만 7세(초등학교 1학년)까지의 3차 년도 (6-8차) 자료를 사용하였다. PSKC는 층화다단계 표본 추출법 을 적용하여 연구대상자들을 추출하였다. 본 연구에서는 예 측변인인 '어머니의 양육스트레스'와 결과변인인 '유아의 공 격적 행동'에 모두 응답한 유아와 어머니 자료를 사용하였으 며, 마지막 8차 년도의 소득을 기준으로 저소득 집단과 중산 집단에 해당하는 중위소득 $100 \%$ (월 평균 422 만원) 이하의 유 아와 어머니 723 쌍의 자료를 활용하였다. 소득수준은 보건복 지부가 보고한 '2015년 국민기초생활보장 수급자 현황'의 기 준에 따라 저소득 집단(중위 $50 \%$ 이하)과 중산 집단(중위 50 $\sim 100 \%)$ 으로 나누었을 때, 저소득 집단은 94명, 중산 집단 은 629 명으로 구성되었다. 6차 년도를 기준으로 어머니의 평 균 연령은 만 35.7세 $(S D=3.88)$, 유아의 월령 만 62개월 $(S D$ $=1.28)$ 로 나타났고, 성별은 남아 371 명 $(51.3 \%)$, 여아 352 명 (48.7\%)으로 구성되어 있었다.

\section{연구도구}

본 연구의 가설 검증을 위해, 육아정책연구소의 한국아동패널 연구에서 사용한 변인들의 측정문항을 사용하였다. 구체적인 변인들과 문항에 대한 측정도구의 내용은 다음과 같다.

\section{양육스트레스}

어머니의 양육스트레스는 Kim \& Kang (1997)의 측정 도구 중 ‘부모역할 수행에 대한 부담감 및 디스트레스’를 발췌하여 사 용하였다. 5점 리커트 척도로, 총 11 문항으로 구성되어 있다. 어머니가 응답하도록 되어있고, 점수가 높을수록 부모 역할에 대한 부담 및 스트레스가 큰 것을 의미한다. 본 척도의 신뢰도 계수(Cronbach's $\alpha$ )는 6차 년도 .87, 7차 년도 .88, 8차 년도 .88 로 나타났다.

\section{온정적 양육행동}

어머니의 양육행동은 Cho, Lee, Lee, 그리고 Kwon (1999)이 개 발한 척도를 한국아동패널연구진이 수정하여 사용한 부모의
양육방식 12 문항 중 온정적 양육에 해당하는 6 문항을 사용하 였다. 5점 척도로 구성되었고, 어머니가 응답하도록 되어있으 며, 점수가 높을수록 온정적 양육의 정도가 높은 것을 의미한 다. 본 척도의 신뢰도 계수(Cronbach's $\alpha$ )는 6차 년도 .84, 7차 년도 .86, 8차 년도.90로 나타났다.

\section{공격적 행동}

유아의 공격행동을 측정하기 위해 6-7차 년도에는 Achenbach 와 Rescorla (2000)의 척도를 Oh와 Kim (2009)이 한국판으 로 표준화한 유아행동평가척도(Child Behavior Checklis 1.55 [CBCL 1.5-5])에서 공격적 행동을 측정하는 19 문항을 사용 하였고, 8차 년도에는 Oh, Kim, Ha, Lee, 그리고 Hong (2010) 이 Achenbach와 Rescorla (2001)의 척도를 한국판으로 표준 화한 아동청소년 행동평가척도(Child Behavior Checklis 1.5-5 [CBCL 6-18]) 중 공격적 행동 측정 18 문항을 사용하였다. 3점 척도로 구성되었고, 어머니가 유아기 자녀의 행동을 바탕으 로 응답하였다. 점수가 높을수록 공격적 문제행동이 높은 것 을 의미하며, 도구 개발자인 육아정책연구소의 기준에 따라 3 차 년도의 $\mathrm{T}$ 점수를 사용하였다. 본 연구에서 유아의 공격적 행동을 측정한 척도의 신뢰도 계수(Cronbach's $\alpha$ )는 6차 년도 $.86,7$ 차년도 $.86,8$ 차 년도 .84로 나타났다.

\section{자료분석}

연구대상의 인구학적 특성 및 주요 변인들에 대한 기술통계분 석은 SPSS 26.0 (IBM Co., Armonk, NY)을 사용하여 산출하였 다. 시간에 따른 어머니의 양육스트레스, 온정적 양육행동, 유 아의 공격적 행동의 인과관계를 종단적으로 살펴보기 위하여 AMOS 23.0 (IBM Co., Armonk, NY) 프로그램을 사용하여 자 기회귀 교차지연 모형(Autoregressive cross-lagged model)을 설정 하고 분석하였다. 본 연구에서 검증한 자기회귀 교차지연 모형 은 Figure 1과 같다. Cole과 Maxwell (2003)의 제안에 따라 어머 니의 양육스트레스, 온정적 양육행동, 유아의 공격성을 대표하 는 각각의 측정변수들에 대한 모형의 적합도 평가를 시행하였 고, 시간적 경과에 따른 잠재변인들의 경로를 분석하였다. 변인 들 간의 회귀계수의 동일성을 확인하기 위해 본 연구에서는 어 머니의 양육스트레스, 온정적 양육행동, 유아의 공격적 행동을 3 년간 측정한 종단자료를 사용하였으며, 결측치 처리를 위해 완전최대우도법(Full Information Maximum Likelihood Method) 을 사용하였다. 검증모형의 적합도 평가는 $\chi^{2}$, 절대적합지수 


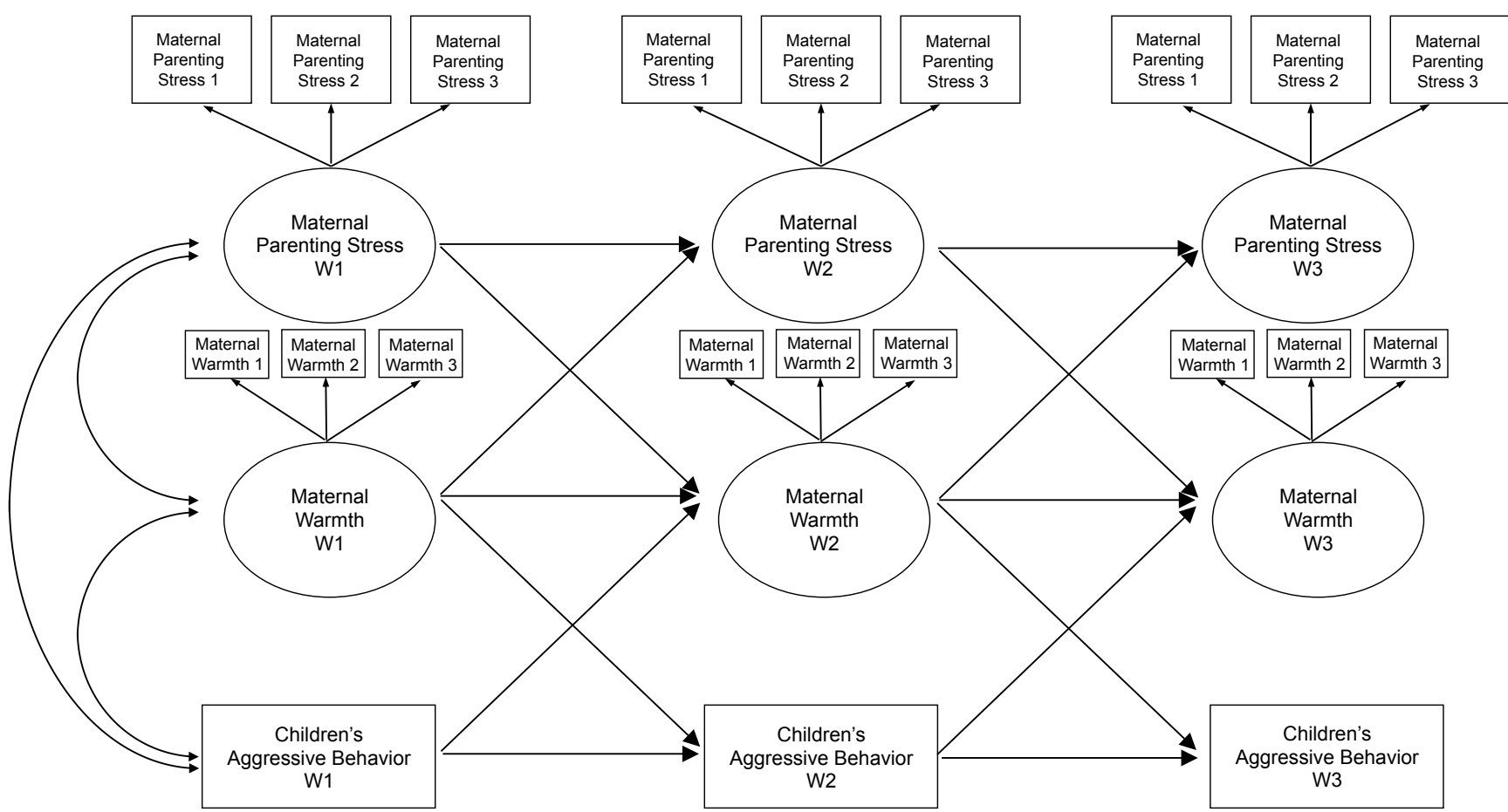

Figure 1. Autoregressive cross-lagged model of maternal parenting stress, maternal warmth, and children's aggressive behavior.

RMSEA, 증분적합지수 CFI와 TLI를 확인하였다. 그러나 $\chi^{2}$ 차 이검증은 표본의 크기에 민감하여 영가설을 쉽게 기각하는 경 향이 있으므로 그 결과를 엄격히 사용하지 않았다. 적합도 지수 는 CFI와 TLI가 .90이상이고, RMSEA가 .06이하일 때 좋은 적 합도로 평가하였다(Hu \& Bentler, 1999).

종단적 매개효과에 대한 통계적 유의성을 검증하기 위해 서는 Shrout와 Bolger (2002)의 제안에 따라 Bootstrapping으로 추정된 경험적분포에 근거한 $95 \%$ 의 신뢰구간을 사용하였다. Bootstrapping은 모집단의 분포를 모를 때 표본을 반복 추출하 여 경험적 분포를 얻고, 그 분포를 통해 모집단의 분포를 추정 한다. 따라서 분포의 정상성을 가정하지 않고 표본자료를 기 초로 경험적 분포를 형성할 수 있는 Bootstrapping을 사용하였 고, $95 \%$ 신뢰구간이 0 을 포함하지 않을 때 통계적으로 유의하 다고 해석하였다(Shrout \& Bolger, 2002).

\section{Results}

\section{주요 변인의 기술 통계 및 상관분석}

본 연구에 사용된 변인들의 기술통계는 Table 1 에 제시하였다. 어머니의 양육스트레스, 온정적 양육행동, 유아의 공격적 행
동은 세 시점에 걸쳐 비슷한 수준을 보였다. 왜도의 절대값이 3 미만, 첨도의 절대값이 10 미만이라는 기준(Kline, 2015)에 부 합하여 정규성 조건이 충족됨이 확인되었다. Pearson 상관분석 결과는 Table 2 와 같고, 변인들 간의 상관은 동일 측정시기 및 측정시기 간에 모두 유의하였다 $(p<.01)$.

\section{저소득 집단과 중산 집단의 어머니의 양육스 트레스, 온정적 양육행동, 유아의 공격적 행동 간의 자기회귀교차지연 모형 검증}

어머니의 양육스트레스, 온정적 태도, 유아의 공격적 행동 간 의 종단적 관계를 저소득 집단과 중산 집단 간에 차이를 보기 위하여, 먼저 두 집단이 동일한 모형으로 적용하여 비교할 수 있는지 알아보고자 형태동일성(configural invariance) 검증을 실시하였다. 저소득 집단과 중산 집단에 동일한 모형이 적절 해야만 추정치를 비교할 수 있으므로, 최적의 모형을 찾기 위 해 아래의 경쟁모형들을 설정하여 비교하였다. 구체적인 모형 에 대한 설명은 다음과 같다.

모형 1: 어떠한 제약도 가하지 않은 기저모형

모형 2: 잠재변수에 해당하는 측정변인들의 요인부하량을 시 점별로 동일하게 제약을 가한 모형

모형 3: 어머니의 양육스트레스의 자기회귀계수에 동일성 제 
Table 1

Descriptive Statistics of Major Variables

\begin{tabular}{|c|c|c|c|c|}
\hline & $M$ & $S D$ & Skewness & Kurtosis \\
\hline \multicolumn{5}{|l|}{ Maternal parenting stress(MPS) } \\
\hline MPS of 5 years old children (wave 1) & 2.68 & 0.64 & 0.06 & 0.06 \\
\hline MPS of 6 years old children (wave 2) & 2.59 & 0.65 & 0.17 & -0.03 \\
\hline MPS of 7 years old children (wave 3) & 2.44 & 0.69 & 0.23 & 0.00 \\
\hline \multicolumn{5}{|l|}{ Maternal warmth(MW) } \\
\hline MW of 5 years old children (wave 1) & 3.60 & 0.54 & 0.01 & 0.21 \\
\hline MW of 6 years old children (wave 2) & 3.61 & 0.55 & -0.18 & 0.38 \\
\hline MW of 7 years old children (wave 3) & 3.66 & 0.56 & -0.16 & 0.21 \\
\hline \multicolumn{5}{|l|}{ Children's aggressive behavior(CAB) } \\
\hline CAB of 5 years old children (wave 1) & 52.85 & 4.99 & 1.93 & 3.35 \\
\hline CAB of 6 years old children (wave 2) & 52.48 & 4.85 & 2.17 & 4.18 \\
\hline CAB of 7 years old children (wave 3 ) & 54.13 & 5.82 & 1.89 & 6.14 \\
\hline
\end{tabular}

Table 2

Correlations of Analyzed Variables

\begin{tabular}{|c|c|c|c|c|c|c|c|c|c|}
\hline & 1 & 2 & 3 & 4 & 5 & 6 & 7 & 8 & 9 \\
\hline 1 & - & & & & & & & & \\
\hline 2 & $.748^{* * *}$ & - & & & & & & & \\
\hline 3 & $.670^{* * *}$ & $.732^{* * *}$ & - & & & & & & \\
\hline 4 & $-.521^{* * *}$ & $-.465^{* * *}$ & $-.421^{* * *}$ & - & & & & & \\
\hline 5 & $-.480^{* * *}$ & $-.638^{* * *}$ & $-.485^{* * *}$ & $.695^{* * *}$ & - & & & & \\
\hline 6 & $-.370^{* * *}$ & $-.447^{* * *}$ & $-.566^{* * *}$ & $.672^{* * *}$ & $.720^{* * *}$ & - & & & \\
\hline 7 & $.354^{* * *}$ & $.316^{* * *}$ & $.303^{* * *}$ & $-.247^{* * *}$ & $-.241^{* * *}$ & $-.196^{* * *}$ & - & & \\
\hline 8 & $.300^{* * *}$ & $.358^{* * *}$ & $.346^{* * *}$ & $-.198^{* * *}$ & $-.255^{* * *}$ & $-.203^{* * *}$ & $.621^{* * *}$ & - & \\
\hline 9 & $.225^{* * *}$ & $.229^{* * *}$ & $.333^{* * *}$ & $-.216^{* * *}$ & $-.239^{* * *}$ & $-.258^{* * *}$ & $.492^{* * *}$ & $.546^{* * *}$ & - \\
\hline
\end{tabular}

Note. $N=723.1$ = Maternal parenting stress w1; 2 = Maternal parenting stress w2; 3 = Maternal parenting stress w3; 4 = Maternal warmth w1; 5 = Maternal warmth w2; 6 = Maternal warmth w3; 7 = Children's aggressive behavior w1; 8 = Children's aggressive behavior w2; $9=$ Children's aggressive behavior $\mathrm{w} 3$.

${ }^{*} p<.05 .{ }^{* *} p<.01 .{ }^{* * *} p<.001$.

약을 가한 모형

모형 4: 어머니의 온정적 양육행동의 자기회귀계수에 동일성 제약을 가한 모형

모형 5: 유아의 공격적 행동의 자기회귀계수에 동일성 제약을 가한 모형

모형 6: 어머니의 온정적 양육행동의 양육스트레스에 대한 교

차회귀계수에 동일성 제약을 가한 모형

모형 7. 어머니의 양육스트레스에 대한 온정적 양육행동의 교

차회귀계수에 동일성 제약을 가한 모형

모형 8: 유아의 공격적 행동에 대한 어머니의 온정적 양육행동

의 교차회귀계수에 동일성 제약을 가한 모형

모형 9: 어머니의 온정적 양육행동에 대한 유아의 공격적 행동

\section{의 교차회귀계수에 동일성 제약을 가한 모형}

모형 10: 어머니의 양육스트레스, 온정적 양육행동, 유아의 공격 적 행동의 오차공분산 간에 동일성 제약을 가한 모형

각 모형은 서로 내재된(nested) 관계로 모형을 비교할 때 $\chi^{2}$ 차이검증 적용이 가능하다. 하지만, $\chi^{2}$ 차이검증은 표본의 크 기에 민감하기 때문에 CFI, TLI, RMSEA를 통합적으로 고려하 였다. 모형비교 시 모형의 CFI가 .01만큼 작아지거나(Cheung \& Resvold, 2002), TLI가 .02만큼 줄어들거나(Vandenberg \& Lence, 2000), RMSEA가 .015보다 커졌을 때 적합도 지수가 유 의하게 나빠졌다고 해석하였다(Chen, 2007). 따라서 비교모형 중 적합도 지수가 유의하게 나빠지지 않았을 때에는 동일성이 성립된다 가정할 수 있으므로 두 모형 중 더욱 간명한 이후 모 
Table 3

Results of Configural Invariance Testing for low- and middle-income group

\begin{tabular}{cccccccccccc}
\hline & \multicolumn{4}{c}{ the low-income group } \\
\cline { 2 - 11 } Model & $\chi^{2}$ & $d f$ & CFI & TLI & RMSEA & $\chi^{2}$ & $d f$ & CFI & TLI & RMSEA \\
\hline 1 & 170.522 & 150 & .987 & .982 & .038 & 351.008 & 150 & .979 & .971 & .046 \\
2 & 184.985 & 158 & .983 & .977 & .043 & 366.276 & 158 & .978 & .971 & .046 \\
3 & 194.388 & 159 & .977 & .970 & .049 & 366.356 & 159 & .978 & .971 & .046 \\
4 & 196.246 & 160 & .977 & .970 & .049 & 367.651 & 160 & .978 & .972 & .045 \\
5 & 196.520 & 161 & .977 & .970 & .049 & 384.007 & 161 & .977 & .970 & .047 \\
6 & 196.714 & 162 & .978 & .971 & .048 & 390.405 & 162 & .976 & .969 & .047 \\
7 & 197.274 & 163 & .978 & .972 & .048 & 390.674 & 163 & .976 & .969 & .047 \\
8 & 197.452 & 164 & .979 & .973 & .047 & 393.121 & 164 & .976 & .969 & .047 \\
9 & 197.458 & 165 & .979 & .974 & .046 & 396.288 & 165 & .976 & .969 & .047 \\
10 & 202.302 & 168 & .978 & .973 & .047 & 399.249 & 168 & .976 & .970 & .047 \\
\hline
\end{tabular}

Note. the low-income group $(\mathrm{n}=94)$, the middle-income group $(\mathrm{n}=629) .1$ = baseline; 2 = metric invariance across time of MPS, MW, and $\mathrm{CAB} ; 3$ = structural invariance across time of MPS; 4 = structural invariance across time of MW; 5 = structural invariance across time of CAB; 6 = structural invariance across time of MPS to MW; 7 = structural invariance across time of MW to MPS; $8=$ structural invariance across time of MW to $\mathrm{CAB} ; 9$ = structural invariance across time of $\mathrm{CAB}$ to $\mathrm{MW} ; 10=$ error covariance invariance across time.

형을 선택하였다. 최적의 모형을 선정하기 위해 모형 1 에서부 터 모형 10 까지 순차적으로 비교한 결과는 Table 3과 같다.

먼저, 기저모형인 모형 1과 측정동일성 제약을 가한 모형 2 를 비교한 결과, 두 집단 모두 CFI와 TLI가 .01 안으로 감소하 거나 동일하고, RMSEA가 동일하거나 .015 안으로 증가하여, 시간에 따른 측정동일성이 확인되었다. 이는 시간의 흐름에 따라 어머니의 양육스트레스, 온정적 행동, 유아의 공격적 행 동에 대해 동일하게 해석되었음을 의미한다. 각 잠재변수의 자기회귀계수에 대한 동일성 제약을 가한 모형 3, 모형 4, 모 형 5 를 모형 2와 순차적으로 비교했을 때, CFI와 TLI가 근소하 게 감소하였고, RMSEA가 동일하거나 .015보다 작게 증가하 여 자기회귀계수의 동일성이 충족되었다. 즉, 어머니의 양육 스트레스, 온정적 양육행동, 유아의 공격적 행동에 대해 각각 6차 년도 값이 7차년도에 미치는 영향력과 7차 년도 값이 8차 년도에 미치는 영향력의 정도가 동일한 것으로 나타났다. 모 형 6부터 모형 9까지는 각 시점에서 교차회귀계수에 동일성 을 가한 모형이다. 이를 순차적으로 모형 5 와 비교한 결과, 모 형 6, 모형 7, 모형 8, 모형 9의 CFI와 TLI가 근소하게 감소하거 나 증가 혹은 동일하고, RMSEA가 동일하거나 근소하게 감소 하여, 모형 9의 경로 동일성이 확인되었다. 즉, 어머니의 온정 적 양육행동의 양육스트레스에 대한 교차지연회귀효과, 어머 니의 양육스트레스에 대한 온정적 양육행동의 교차지연회귀 효과, 유아의 공격적 행동에 대한 어머니의 온정적 양육행동 의 교차지연회귀효과, 어머니의 온정적 양육행동에 대한 유아 의 공격적 행동의 교차지연회귀효과가 모두 시간의 흐름에 따
라 동일하다는 것을 나타냈다. 마지막으로 오차공분산을 동일 하게 제약한 모형 10 을 모형 9 와 비교한 결과, 적합도에 문제 가 없으므로 모형 10 을 저소득 집단과 중산 집단의 최종모형 으로 채택하였다. 즉, 저소득 집단과 중산 집단 모두 모형 10 이 적합한 것으로 나타나 집단 간 형태동일성이 만족되었다.

다음으로, 저소득 집단과 중산 집단의 자기회귀계수와 교 차지연 계수가 통계적으로 유의한 차이가 있는지 알아보기 위 해 구조동일성(structural invariance)검증을 실시하였다. 이때 측정동일성(metric invariance)이 구조동일성의 사전가정으로 충족되어야 하기 때문에, 측정동일성을 검증하고 다중집단분 석(multi-group analysis)을 실시하였다. 다중집단분석을 위한 동일성검증에서는 위의 형태동일성을 위한 모형 비교와 동일 한 기준을 적용하여 최적 모형을 검증하였다. 검증된 10 개 모 형에 대한 결과는 Table 4와 같다.

저소득 집단과 중산 집단을 동시에 분석하지만 집단 사이 에 동일화 제약을 가하지 않은 기저모형 1 과 두 집단 간의 측 정변인들의 요인계수를 시간에 따라 동일하게 제약한 모형 2 와의 비교 결과, CFI가 동일하고, TLI가 증가하며, RMSEA가 동일하였다. 즉, 시간에 따른 어머니의 양육스트레스, 온정적 양육행동, 유아의 공격적 행동의 측정동일성이 충족되었다. 다음으로 두 집단의 자기회귀계수와 교차지연 계수가 유의하 게 차이가 있는지 확인하기 위해 각각의 경로에 제약을 가하 여 구조동일성을 검증하였다. 각 잠재변수의 자기회귀계수 에 대한 동일성 제약을 가한 모형 3, 모형 4, 모형 5를 모형 2 와 비교했을 때, CFI와 TLI가 근소하게 감소하였고, RMSEA 
Table 4

Metric Invariance and Structural Invariance Testing Results

\begin{tabular}{lccccc}
\hline Model & $\chi^{2}$ & $d f$ & CFI & TLI & RMSEA \\
\hline 1 & 522.474 & 300 & .980 & .972 & .032 \\
2 & 536.345 & 312 & .980 & .973 & .032 \\
3 & 544.237 & 315 & .979 & .973 & .032 \\
4 & 546.148 & 318 & .980 & .973 & .032 \\
5 & 569.287 & 321 & .978 & .971 & .033 \\
6 & 579.074 & 324 & .977 & .970 & .033 \\
7 & 583.004 & 327 & .977 & .971 & .033 \\
8 & 587.040 & 330 & .977 & .971 & .033 \\
9 & 591.245 & 333 & .977 & .971 & .033 \\
10 & 623.046 & 347 & .975 & .970 & .033 \\
\hline
\end{tabular}

Note. $N=723.1$ = baseline; 2 = metric invariance across time of MPS, MW, and CAB; $3=$ structural invariance across time of MPS; $4=$ structural invariance across time of MW; 5 = structural invariance across time of CAB; 6 = structural invariance across time of MPS to MW; 7 = structural invariance across time of MW to MPS; 8 = structural invariance across time of MW to CAB; $9=$ structural invariance across time of $\mathrm{CAB}$ to $\mathrm{MW} ; 10$ = error covariance invariance across time.

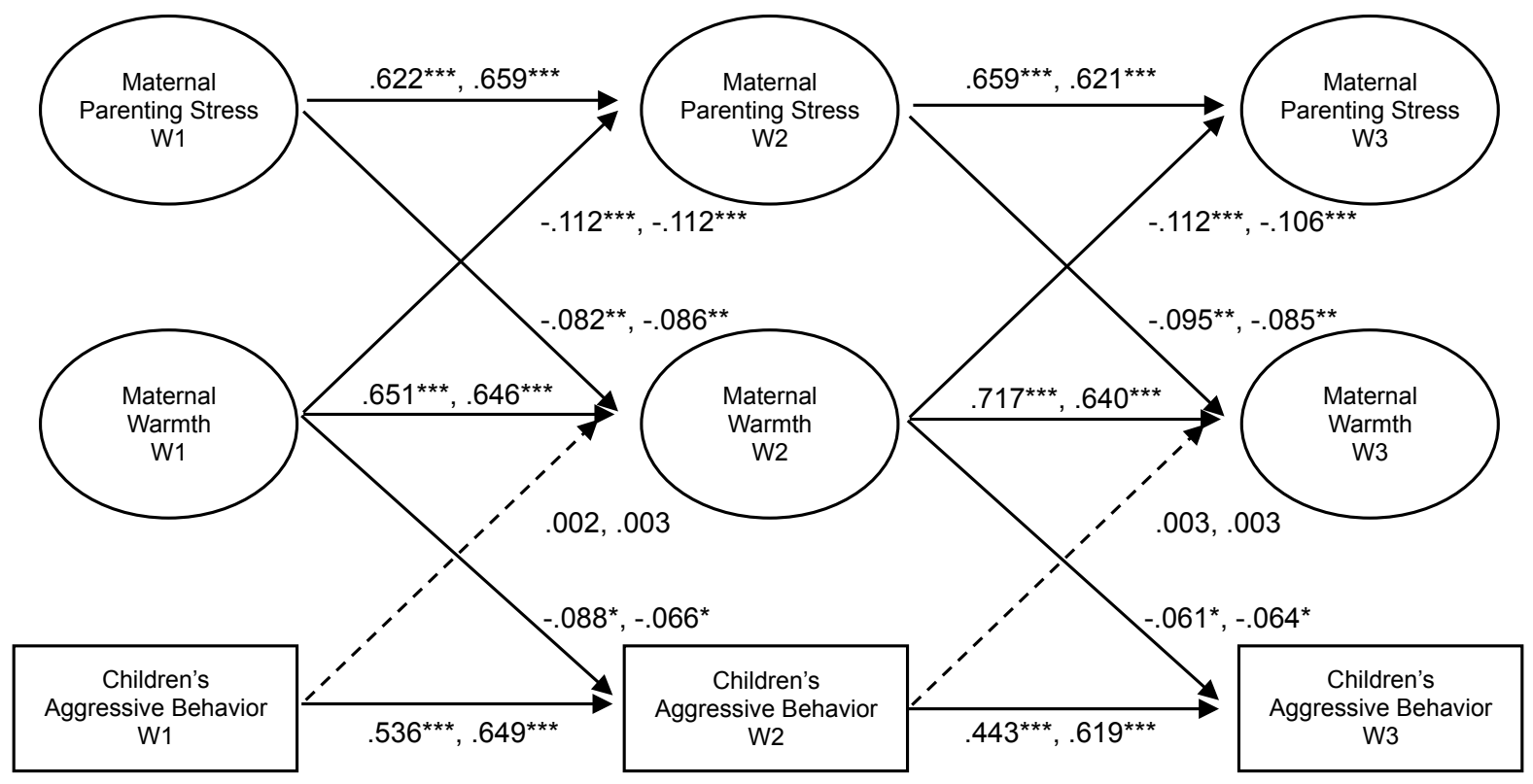

Figure 2. Autoregressive cross-lagged effect of maternal parenting stress, maternal warmth, and children's aggressive behavior for the low-income group (left) and the middle-income group (right): Standardized coefficients.

${ }^{*} p<.05 .{ }^{* *} p<.01$. ${ }^{* * *} p<.001$.

가 증가하여, 두 집단 간 자기회귀계수의 동일성이 충족되었 다. 즉, 어머니의 양육스트레스, 온정적 양육행동, 유아의 공격 적 행동에 대해 각각 6차 년도 값이 7차 년도에 미치는 영향력 과 7차 년도 값이 8차 년도에 미치는 영향력의 정도가 집단 간 동일한 것으로 나타났다. 각 시점에서 교차회귀계수에 동일 성을 가한 모형 6부터 모형 9를 모형 5와 순차적으로 비교한 결과, 모형 9의 CFI와 TLI가 증가하거나 근소하게 감소하고
RMSEA가 동일하여, 모형 9의 경로 동일성이 확인되었다. 즉, 집단 간 어머니의 온정적 양육행동의 양육스트레스에 대한 교 차지연회귀효과, 어머니의 양육스트레스에 대한 온정적 양육 행동의 교차지연회귀효과, 유아의 공격적 행동에 대한 어머니 의 온정적 양육행동의 교차지연회귀효과, 어머니의 온정적 양 육행동에 대한 유아의 공격적 행동의 교차지연회귀효과가 시 간의 흐름에 따라 동일하다는 것을 나타냈다. 마지막으로 모 
형 9와 집단 간 오차공분산에 동일성 제약을 가한 모형 10 의 적 합도를 비교한 결과, CFI와 TLI가 근소하게 감소하고 RMSEA 의 변화가 없었다. 따라서 동일화 제약이 가장 많이 가해져 가 장 간명한 모형인 모형 10 이 최종모형으로 채택되었다. 이는 집단 간 측정동일성, 구조동일성, 오차공분산동일성이 모두 성 립됨을 의미하며, 본 연구에서 설정한 자기회귀교차지연 모형 이 패널 자료에 적합함을 뜻한다 $\left(\chi^{2}(347)=623.046, p<.001\right.$, $\mathrm{CFI}=.975, \mathrm{TLI}=.970, \mathrm{RMSEA}=.033)$. 즉, 자기회귀 교차지연 모형에서 각각의 효과에 있어 저소득 집단과 중산 집단 간에 나타난 차이는 통계적으로 유의하지 않는 것으로 나타났다. 모 형 10 이 반영된 최종모형은 Figure 2 와 같다.

먼저, 어머니의 양육스트레스의 자기회귀계수 추정치는 6 차 년도에서 7차 년도의 경로(저소득 집단 $\beta=.622, p<.001$, 중 산 집단 $\beta=.659, p<.001), 7$ 차 년도에서 8 차 년도의 경로(저소 득 집단 $\beta=.659, p<.001$, 중산 집단 $\beta=.621, p<.001$ ) 가 모두 정적으로 유의하게 나타났다. 이는 초등학교 입학 전 만 5세부 터 초등학교에 입학한 만 7세에 이르는 동안 어머니의 이전 양 육스트레스가 이후 양육스트레스에 안정적으로 영향을 미침 을 의미한다. 어머니의 온정적 양육행동의 자기회귀계수 추정 치 역시 6차 년도에서 7차 년도의 경로(저소득 집단 $\beta=.651$, $p<.001$, 중산 집단 $\beta=.646, p<.001), 7$ 차 년도에서 8 차 년도 의 경로(저소득 집단 $\beta=.717, p<.001$, 중산 집단 $\beta=.640, p<$ .001)가 모두 정적으로 유의하게 나타났다. 즉, 아동이 만 5세 때 어머니의 온정적인 양육행동은 아동이 초등학교 1학년이 될 때까지 시간의 변화에도 불구하고 점점 더 안정적으로 지 속됨을 알 수 있다. 유아의 공격적 행동에 대한 자기회귀계수 추정치는 6차 년도에서 7차 년도의 경로(저소득 집단 $\beta=.536$, $p<.001$, 중산 집단 $\beta=.649, p<.001)$, 7차 년도에서 8차 년도 의 경로(저소득 집단 $\beta=.443, p<.001$, 중산 집단 $\beta=.619, p<$ .001)가 모두 정적으로 유의하게 나타났다. 이는 유아의 공격 적인 행동이 만 5 세에서 만 7세에 이르기까지 시간이 지남에 따라 점점 더 안정적으로 유지됨을 알 수 있는 결과이다.

다음으로, 어머니의 양육스트레스와 온정적 양육행동 간 시간의 경과에 따른 인과적 관계를 살펴보았다. 교차지연 계 수의 추정지를 확인한 결과, 6 차 년도 어머니의 양육스트레스 에서 7차 년도 온정적 양육행동의 경로(저소득 집단 $\beta=-.082$, $p<.01$, 중산 집단 $\beta=-.086, p<.01), 7$ 차 년도 어머니의 양육 스트레스에서 8 차 년도 온정적 양육행동의 경로(저소득 집단 $\beta=-.095, p<.01$, 중산 집단 $\beta=-.085, p<.01$ )가 모두 부적으 로 유의하였다. 교차지연 계수가 매년 통계적으로 유의하게 부적으로 유지되고 있음은 어머니의 양육스트레스가 이후의
온정적 양육행동을 낮추는 영향관계가 일관됨을 의미한다. 6 차 년도 어머니의 온정적 양육행동에서 7차 년도 양육스트레 스의 경로(저소득 집단 $\beta=-.112, p<.01$, 중산 집단 $\beta=-.112$, $p<.01), 7$ 차 년도 온정적 양육행동에서 8차 년도 양육스트레 스의 경로(저소득 집단 $\beta=-.112, p<.01$, 중산 집단 $\beta=-.106$, $p<.01)$ 역시 모두 부적으로 유의하여, 어머니의 온정적 양육 행동이 증가될수록 이후 양육스트레스가 일관되게 감소됨을 나타냈다.

또한, 어머니의 온정적 양육행동과 유아의 공격적 행동 간 의 시간 경과에 따른 인과적 관계를 살펴보았다. 6 차 년도 어 머니의 온정적 양육행동에서 7 차 년도 유아의 공격행동의 경 로(저소득 집단 $\beta=-.088, p<.05$, 중산 집단 $\beta=-.066, p<.05$ ), 7 차 년도 온정적 양육행동에서 8 차 년도 유아의 공격행동의 경로(저소득 집단 $\beta=-.061, p<.05$, 중산 집단 $\beta=-.064, p<$ $.05)$ 가 모두 부적으로 유의하였다. 이는 학령 전 어머니의 온 정적 양육행동이 증가할수록 이후 유아의 공격행동이 일관되 게 감소함을 의미한다. 반면, 6 차 년도 유아의 공격행동에서 7 차 년도 어머니의 온정적 양육행동의 경로(저소득 집단 $\beta=$ $.002, p=.88$, 중산 집단 $\beta=.003, p=.88), 7$ 차 년도 유아의 공 격행동에서 8 차 년도 어머니의 온정적 양육행동의 경로(저소 득 집단 $\beta=.003, p=.88$, 중산 집단 $\beta=.003, p=.88$ )는 모두 통계적으로 유의하지 않았다. 즉, 유아의 공격적 행동은 이후 어머니의 온정적 양육행동을 예측하지 못함을 알 수 있다.

마지막으로, 6차 년도 어머니의 양육스트레스가 7차 년도 온정적 양육행동을 통해 8 차 년도 유아의 공격행동에 이르 는 종단적 매개효과를 확인하기 위해 Shrout와 Bolger(2002) 의 제안에 따라 Bootsrapping을 사용하였다. 양육스트레스가 온정적 양육행동을 매개로 유아의 공격행동에 이르는 매개를 1000 번 반복 추출하여 Bootsrapping 한 결과, $95 \%$ 신뢰구간에 서 간접효과의 범위가 .008 .111로 0을 포함하고 있지 않기 때문에, 간접효과가 유의함이 확인되었다 $(\beta=.005, p<.01)$.

\section{Discussion}

본 연구는 학령 전 만 5세에서 6세 및 만 7세(초등학교 1학년) 까지의 어머니의 양육스트레스, 온정적 양육행동, 유아의 공격 적 행동 간 시간의 변화에 따른 안정성과 변인들 간의 관계에 대한 소득수준의 차이를 살펴보기 위해, 한국아동패널(PSKC) 의 6-8차 자료를 활용하여 자기회귀교차지연 모형을 설정하고 다중집단분석을 실시하였다. 이에 따른 결과는 다음과 같다. 
첫째, 어머니의 양육스트레스, 온정적 양육행동, 유아의 공 격적 행동 각각의 변인들이 모두 시간이 지남에 따라 안정적 으로 정적인 영향을 예측하는 것으로 나타났다. 먼저 유아가 만 5세에서 7세까지 연령이 증가하는 동안 어머니의 양육스 트레스가 안정적으로 지속됨을 확인하였다. 이는 영유아기 자 녀를 둔 어머니의 양육스트레스가 시간이 지나도 안정적으 로 계속 누적된다는 이전 연구결과(Crnic et al., 2005)와 일치 한다. 또한, 시간에 따른 어머니의 양육스트레스 변화는 소득 수준 간 차이가 없었다. 즉, 소득수준에 관계없이 유아의 연령 이 증가함에 따라 어머니가 경험하는 양육스트레스가 안정적 으로 증가하였다. 이러한 결과는 초기 양육스트레스를 해결하 지 않을 시 자녀가 성장함에 따라 어머니가 계속적으로 갖게 되는 양육에 대한 스트레스가 배가 될 수 있으므로, 초기에 적 절히 대처할 수 있도록 부모교육 또는 사회적 지원이 필요함 을 시사한다. 다음으로 이전 시점 어머니의 온정적 양육행동 이 이후 시점으로 갈수록 안정적으로 유지되었고, 이러한 변 화에 대한 소득수준 간의 차이는 없었다. 이는 유아기 자녀를 둔 부모의 온정적 양육행동이 시간이 지남에 따라 안정적으로 유지된 이전 연구결과(Rothenberg et al., 2020)와 같은 결과이 다. 또한, 유아의 공격행동은 만 5세, 6세, 7세가 될 때까지 모 두 지속적으로 이후 시점에 영향을 미치고, 이러한 관계는 소 득수준에 차이가 없었다. 이는 유아의 공격행동이 일시적이지 않고, 또래를 포함한 주변 관계와의 부정적 상호작용을 통해 공격적인 행동이 강화되었던 선행연구결과와 일치한다(Shin, 2012). 이러한 연구결과는 사회적 관계 형성에 결정적 시기인 초등학교 1학년 유아가 공격행동으로 인해 관계 형성에 어려 움을 겪지 않도록, 학령 전기 공격행동에 대한 조기개입의 필 요성을 시사하는 바이다.

둘째, 시간의 경과에 따른 어머니의 양육스트레스와 온정 적 양육행동 간의 양방향적 관계가 확인되었다. 먼저, 양육스 트레스가 높을수록 온정적 양육이 감소하였고, 이러한 결과에 있어 저소득 집단과 중위소득 집단 간의 차이가 없었다. 이는 소득수준에 관계없이 양육스트레스가 높은 어머니는 스스로 어머니로서의 자격에 대한 좌절이나 공포 같은 부정적 감정을 느낌으로써 심리적 유연성이 떨어지게 되고, 아동과 상호작용 을 해야 하는 상황에서 보다 높은 수준의 통제나 처벌 혹은 회 피방식 같은 덜 온정적인 양육행동을 보이게 되는 것으로 설 명된다(Fonseca, Moreira, \& Canavarro, 2020). 또한, 온정적 양 육행동이 높은 어머니일수록 이후 양육스트레스가 감소하였 고, 이러한 결과에 있어 저소득 집단과 중위소득 집단 간의 차 이가 없었다. 이는 부모가 자녀의 요구에 민감하게 반응하고
온정적인 양육방식을 사용했을 때 유아의 책임감이나 목적을 추구하는 자기주도성 발달에 긍정적으로 영향을 미치게 되어 (Baumrind, 1971), 부모로 하여금 양육에 대한 부담이 감소될 수 있음을 예측하는 바이다.

셋째, 시간의 경과에 따른 어머니의 온정적 양육행동과 유 아의 공격적 행동 간의 관계를 확인하였다. 그 결과, 어머니의 온정적 양육행동이 높을수록 유아의 공격행동이 낮아졌고, 온 정적 양육행동이 공격행동에 미치는 영향은 시간에 따라 변 하지 않았다. 이러한 영향은 저소득 집단과 중위소득 집단 간 에 차이가 없었다. 이는 어머니의 온정적 양육태도가 유아의 정서조절능력을 발달시켜 공격행동을 감소시킨 이전 연구 결 과(I. S. Kim, Kim, \& Kim, 2010)와 맥을 함께 하는 결과이다. 반면, 이전 시점 유아의 공격행동이 이후 시점 어머니의 온정 적 양육행동에 미치는 영향은 유의하지 않았다. 유아의 공격 행동과 어머니의 온정적 양육행동 간에 유의한 부적 상관관계 가 있음에도 불구하고(Table 1), 교차회귀계수 추정치가 온정 적 양육행동에서 유아의 공격행동으로의 경로에서만 유의함 을 보았을 때, 두 변인의 인과적 관계는 일방향적 이라는 것을 추론할 수 있다. 이는 유아기 아동의 경우, 부모의 문제행동에 대한 지적이 부정적인 표현을 사용하는 정도만으로도 어떤 행 동이 용인되지않는 행동임을 알아차리기 때문에, 처벌과 같은 혹독한 양육방식을 사용하지 않아도 된다는 선행연구(Wang $\& \mathrm{Liu}, 2018)$ 로 설명된다.

넷째, 어머니의 온정적 양육행동은 양육스트레스가 유아 의 공격적 행동에 미치는 관계를 종단적으로 매개하였다. 그 리고 이 관계는 소득수준에 따른 집단 간 차이가 나타나지 않 았다. 즉, 저소득 집단과 중위소득 집단에서 모두 어머니의 높 은 양육스트레스가 온정적 양육행동을 감소시키고, 이러한 양 육행동방식이 유아의 공격행동을 강화시키는 결과를 가져옴 을 의미한다. 이는 선행연구와 맥을 함께하는 결과로(Carapito, Ribeiro,Pereira, \& Roberto, 2020), 유아기 자녀를 둔 어머니가 높은 수준의 양육 스트레스를 경험하게 되면 심리적 유연성 이 낮아져 자녀에게 부정적인 양육방법으로 상호작용하게 되 고, 이러한 양육 아래에서 자란 유아는 공격적인 행동과 외현 화 문제를 더 많이 일으킬 수 있다는 것을 의미한다(Burke \& Moore, 2015). 다시 말해서, 어머니의 온정적인 양육행동은 유 아기 자녀의 공격적 행동을 감소시키는 효과가 있으며, 온정 적 양육행동을 증진시키기 위해서는 어머니가 양육과 관련된 스트레스를 잘 관리해야 함을 시사한다. 하지만, 양육스트레 스, 온정적 양육행동, 유아의 공격행동 간의 관계는 저소득 집 단과 중산 집단에서 차이를 보이지 않았다. 이러한 결과는 소 
득수준이 어머니의 스트레스, 양육행동, 유아의 공격성에 영 향을 미친다는 선행연구(Dodge et al., 1994)와 다소 일치하지 않는 결과이다. 이는 경제적 수준이 유아의 행동문제를 예측하 는 변인들 간의 관계를 살펴볼 때, 경제적 수준을 포함하여 이 와 관련된 다양한 변인들을 함께 살펴보아야 한다는 선행연구 (Sullivan., Forehand, Vreeland, \& Compas, 2021)로 설명가능하 다. 즉, 소득수준은 단일 변인으로 다른 변인들에 미치는 영향 보다, 경제적 수준에 대한 어머니의 대처방식, 어머니의 우울 수준, 어머니의 교육수준, 사회에서 받는 재정적 지원, 한부모 가정 등과 같은 경제수준과 관련된 다른 변인들과의 상호작용 을 통해 자녀에게 더 크게 영향을 미친다(Sullivan et al., 2021). 하지만 본 연구에서는 소득수준이라는 단일 변인으로 집단을 나누어 변인들 간의 관련성에 대해 살펴보았기 때문에, 소득수 준과 함께 상호작용하여 부모-자녀에게 미치는 영향을 다각도 로 살펴보는 데에 제한이 있었다. 따라서 후속연구에서 소득수 준과 함께 상호작용하는 부모의 심리 사회적 변인들을 함께 살 펴본다면, 소득수준이 부모-자녀 관계 및 유아의 발달에 미치 는 영향에 대한 더욱 구체적 설명이 가능할 것으로 예상된다. 또한, 본 연구에서는 낮은 소득이 변인들 간의 관련성에 미치 는 영향을 살펴보기 위해, 저소득 집단과 보다 일반적인 중위 소득 집단만을 비교하였다. 본 연구를 바탕으로, 소득수준이 미치는 영향을 더 넓은 차원으로 보기 위해서는 고소득 집단을 추가하여 함께 비교하는 추후 연구가 필요할 것이다.

본 연구의 제한점 및 후속연구를 위한 제언은 다음과 같다. 첫째, 본 연구에서는 패널데이터를 사용함에 있어, 유아의 공 격성 측정을 위해 사용한 6-7차 년도의 척도와 8차 년도의 척 도에 차이가 있었다. 원칙적으로 만 18 개월부터 만 5세까지 는 유아행동평가척도 CBCL 1.5-5를 사용하고, 만 6세부터 CBCL 6-18를 사용해야 한다. 하지만, CBCL 6-18이 학령기 생 활을 중점으로 측정하기 때문에 6-7차 년도(만 5-6세)는 CBCL 1.5-5를 사용하고, 8차 년도(만 7세)에는 CBCL 6-18을 사용한 것으로 보고되었다. 따라서 본 연구에서는 척도 개발 연구진 의 메뉴얼에 기반하여 세 시점의 $\mathrm{T}$ 점수를 사용하였다. 세 시 점의 측정동일성 검증에서 유의한 차이가 없었지만, 측정하고 자 하는 변인의 높은 타당도를 위해 추후 연구에서 모든 차수 에서 동일한 측정도구를 사용할 필요가 있다.

둘째, 본 연구에서는 학령 전환기인 초등학교 1학년 유아의 공격적 행동에 영향을 미치는 예측 요인들의 인과적 관계를 살 펴보기 위해 만 5세, 6세, 7세 유아 및 어머니의 자료만을 분석 하였다. 본 연구를 통해 어머니의 양육스트레스가 양육행동을 통해 유아의 공격행동에까지 이르는 매개경로가 확인되었으므
로, 학령 전환을 시작으로 초등학교 1학년 유아를 둔 부모의 양 육스트레스가 이후 유아의 공격행동에 미치는 종단분석도 의 미 있는 연구가 될 것으로 생각한다. 즉, 자녀가 초등학교를 입 학함과 동시에 부모에게 요구되는 역할변화로 인해 어머니는 더 높은 수준의 양육스트레스를 경험할 수 있다. 따라서 자녀가 초등학교에 입학한 시점의 양육 스트레스가 이후 양육행동을 통해 유아의 공격행동에 미치는 매개경로가 유의한지 그리고 변인들 간에 미치는 효과가 학령 전과 후에 변화가 있는지를 살 펴본다면, 유아의 공격행동 및 어머니의 양육스트레스를 위한 적절한 개입 시기를 보다 명확하게 예측할 수 있을 것이다.

본 연구가 갖는 함의는 다음과 같다. 먼저, 본 연구에서는 사회적 관계 형성에 결정적 시기인 초등학교 1학년 시기를 살 펴봄으로써, 유아의 공격행동을 예측하는 변인들 간의 관계를 밝혀, 공격행동 감소에 도움을 줄 뿐만 아니라 유아가 더욱 원 활하게 대인관계를 형성하는 데 도움이 될 수 있는 정보를 제 공했다는 점에서 학문적 의의가 있다.

다음으로, 어머니의 양육스트레스, 온정적 양육행동, 유아 의 공격적 행동 간의 관계 이해를 위해 종단자료를 분석하였기 때문에, 이전 시기의 변수들을 통제할 수 있으므로 변인들 간 의 인과적 추론이 가능하였다. 즉, 반복적으로 측정한 자료들 을 자기회귀 교차지연 모형으로 설정하여 동일 변인이 시간의 경과에 따라 변화하는지를 살펴볼 수 있고, 변인들 간에 미치 는 효과에 일관성이 있는지 확인할 수 있었다. 즉, 어머니의 양 육스트레스, 온정적 양육행동, 유아의 공격행동이 시간이 경과 함에 따라 증가함을 확인할 수 있었다. 이는 유아의 연령이 증 가할수록 어머니의 양육스트레스가 더 많아질 수 있고 유아의 공격적 행동이 증가할 가능성이 높다는 것을 의미하므로, 어머 니의 양육스트레스와 유아의 공격행동에 대한 조기개입이 필 요함을 시사한다. 더하여, 어머니의 온정적 양육이 유아의 공 격적 행동에 직접적으로 영향을 미침이 확인되었기 때문에, 유 아를 지지하고 수용하며 격려하는 양육방식을 사용할 수 있도 록 부모교육이 제공되어야 할 것이다. 또한, 유아의 공격행동 의 주요 예측 요인이면서 매개변인인 어머니의 온정적 양육행 동이 어머니의 스트레스에 많은 영향을 받았으므로, 학령 전 자녀를 가진 어머니가 양육스트레스를 감소시키는 데 도움이 되는 사회적 지지 및 프로그램 개발이 필요함을 시사한다.

마지막으로, 본 연구는 어머니의 양육스트레스, 양육행동, 유아의 공격행동의 관계를 저소득 집단과 중위 소득집단으로 나누어 살펴봄으로써, 세 변인들 간의 관계가 소득수준에 차 이가 없다는 것을 확인할 수 있었다. 따라서 유아의 공격행동 감소를 위한 어머니의 양육스트레스 감소 및 온정적 양육행동 
증진을 위한 개입이 가정의 소득에 관련 없이 모두 적절한 시 기에 필요함을 확인할 수 있었다는 것에 의의가 있다.

\section{Conflict of Interest}

No potential conflict of interest relevant to this article was reported.

\section{References}

\section{In English}

Abidin, R. R. (1992). The determinants of parenting behavior. Journal of Clinical Child Psychology, 21(4), 407-412. doi:10.1207/s15374424jccp2104_12

Achenbach, T. M., \& Rescorla, L. A. (2000). Manual for the ASEBA Preschool Forms \& Profiles. Burlington, VT: University of Vermont, Research Center for Children, Youth, \& Families.

Achenbach, T. M., \& Rescorla, L. A. (2001). Manual for the ASEBA school-age forms \& profiles. Burlington, VT: University of Vermont, Research Center for Children, Youth, \& Families.

Anthony, L. G., Anthony, B. J., Glanville, D. N., Naiman, D. Q., Waanders, C., \& Shaffer, S. (2005). The relationship between parenting stress, parenting behaviour and preschoolers' social competence and behaviour problems in the classroom. Infant and Child Development, 14(2), 133-154. doi:10.1002/icd.385

Baumrind, D. (1971) Current patterns of parental authority. Developmental Psychology Monograph, 4(1, Pt.2). doi: $10.1037 / \mathrm{h} 0030372$

Baydar, N., \& Akcinar, B. (2018). Reciprocal relations between the trajectories of mothers' harsh discipline, responsiveness and aggression in early Childhood. Journal of Abnormal Child Psychology, 46, 83-97. doi:10.1007/s10802-017-0280-y

Blasio P. D., Camisasca, E., Miragoli, S., Ionio, C., \& Milani, L. (2017). Does maternal parenting stress mediate the association between postpartum PTS symptoms and children's internalizing and externalizing problems? A longitudinal perspective. Child \& Youth Care Forum, 46, 685-701. doi:10.1007/s10566-017-9400-7

Bor, W., Najman, J. M., O'Callaghan, M., Williams, G. M., \& Anstey, K. (2001). Aggression and the development of delinquent behaviour in children (Trends and Issues in Crime and Criminal Justice, No. 207). Canberra:
Australian Institute of Criminology.

Broidy, L. M., Nagin, D. S., Tremblay, R. E., Bates, J. E., Brame, B., Dodge, K. A.,...Vitaro, F. (2003). Developmental trajectories of childhood disruptive behaviors and adolescent delinquency: A six-site, cross-national study. Developmental Psychology, 39(2), 222-245. doi:10.1037/00121649.39.2.222

Burke, K., \& Moore, S. (2015). Development of the Parental Psychological Flexibility Questionnaire. Child Psychiatry \& Human Development, 46, 548-557. doi:10.1007/s10578014-0495-x

Carapito, E., Ribeiro, M. T., Pereira, A. I., \& Roberto, M. S. (2020). Parenting stress and preschoolers' socio-emotional adjustment: The mediating role of parenting styles in parent-child dyads. Journal of Family Studies, 26(4), 594610. doi:10.1080/13229400.2018.1442737

Chen, F. F. (2007). Sensitivity of goodness of fit indexes to lack of measurement invariance. Structural Equation Modeling, 14(3), 464-504. doi:10.1080/10705510701301834

Cheung, G. W., \& Rensvold, R. B. (2002). Evaluating goodnessof-fit indexes for testing measurement invariance. Structural Equation Modeling, 9(2), 233-255. doi:10.1207/S15328007 SEM0902_5

Cole, D. A., \& Maxwell, S. E. (2003). Testing mediational models with longitudinal data: Questions and tips in the use of structural equation modeling. Journal of Abnormal Psychology, 112(4), 558-577. doi:10.1037/0021-843X.112.4.558

Cole, P. M., Michel, M. K., \& Teti, L, O. (1994). The Development of emotion regulation and dysregulation: A clinical perspective. In N. A. Fox (Ed.), The development of emotion regulation: Biological and behavioral considerations. Monographs of the Society for Research in Child Development, 59(2-3, Serial No. 240), 73-100. doi:10.2307/1166139

Crnic, K. A., Gaze, C., \& Hoffman, C. (2005). Cumulative parenting stress across the preschool period: Relations to maternal parenting and child behavior at age 5. Infant and Child Development, 14, 117-132. doi:10.1002/icd.384

Dodge, K. A., Lansford, J. E., Burks, V. S., Bates, J. E., Pettit, G. S., Fontaine, R., \& Price, J. M. (2003). Peer rejection and social information-processing factors in the development of aggressive behavior problems in children. Child Development, 74(2), 374-393. doi:10.1111/1467-8624.7402004

Dodge, K. A., Pettit, G. S., \& Bates, J. E. (1994). Socialization mediators of the relation between socioeconomic status and child conduct problems. Child Development, 65(2), 649-665. doi:10.2307/1131407

Ferreira, T., Cadima, J., Matias, M., Vieira, J. M., Leal, T., \& Matos, P. M. (2016). Preschool children's prosocial behavior: The role of mother-child, father-child and 
teacher-child relationships. Journal of Child and Family Studies, 25(6), 1829-1839. doi:10.1007/s10826-0160369-x

Fitzpatrick, S. E., Srivorakiat, L., Wink, L. K., Pedapati, E. V., \& Erickson, C. A. (2016). Aggression in autism spectrum disorder: Presentation and treatment options. Neuropsychiatric Disease and Treatment, 12, 1525-1538. doi:10.2147/NDT.S84585

Fonseca, A., Moreira, H., \& Canavarro, M. C. (2020). Uncovering the links between parenting stress and parenting styles: The role of psychological flexibility within parenting and global psychological flexibility. Journal of Contextual Behavioral Science, 18, 59-67. doi:10.1016/j.jcbs.2020.08.004

Gabler, S., Kungl, M., Bovenschen, I., Lang, K., Zimmermann, J., \& Nowacki, K. (2018). Predictors of foster parents' stress and associations to sensitivity in the first year after placement. Child Abuse \& Neglect, 79, 325-338. doi:10.1016/j.chiabu.2018.02.009

Georgiou, S. N. (2008). Bullying and victimization at school: The role of mothers. British Journal of Educational Psychology, 78(1), 109-125. doi:10.1348/000709907X204363

Granero, R., Louwaars, L., \& Ezpeleta, L. (2015). Socioeconomic status and oppositional defiant disorder in preschoolers: parenting practices and executive functioning as mediating variables. Frontiers in Psychology, 6, 1412. doi:10.3389/ fpsyg.2015.01412

Granic, I., \& Patterson, G. R. (2006). Toward a comprehensive model of antisocial development: A dynamic systems approach. Psychological Review, 113(1), 101-131. doi:10.1037 /0033-295X.113.1.101

Hu, L., \& Bentler, P. M. (1999). Cutoff criteria for fit indexes in covariance structure analysis: Conventional criteria versus new alternatives. Structural Equation Modeling: A Multidisciplinary Journal, 6(1), 1-55. doi:10.1080/1070551 9909540118

Huffman, L. C., Mehlinger, S. L., Kerivan, A. S., Cavanaugh, D. A., Lippitt, J. \& Moyo, O. (2001). Off to a good start: Research on the risk factors for early school problems and selected federal policies affecting children's social and emotional development and their readiness for school. (ED476378)

Kline, R. B. (2015). Principles and practices of structural equation modeling (4th ed.). New York: Guilford Press.

Olson, S. L., Lopez-Duran, N., Lunkenheimer, E. S., Chang, H., \& Sameroff, A. J. (2011). Individual differences in the development of early peer aggression: Integrating contributions of self-regulation, theory of mind, and parenting. Development and Psychopathology, 23(1), 253266. doi: $10.1017 /$ S0954579410000775

Prendergast, S., \& MacPhee, D. (2020). Trajectories of maternal aggression in early childhood: Associations with parenting stress, family resources, and neighborhood cohesion. Child abuse \& neglect, 99, 104315. doi:10.1016/j.chiabu. 2019.104315

Rothenberg, W. A., Lansford, J. E., Al-Hassan, S. M., Bacchini, D., Bornstein, M. H., Chang, L.,. . . Peña Alampay, L. (2020). Examining effects of parent warmth and control on internalizing behavior clusters from age 8 to 12 in 12 cultural groups in nine countries. The Journal of Child Psychology and Psychiatry, 61(4), 436-446. doi:10.1111/ jcpp. 13138

Salimi, N., Karimi-Shahanjarini, A., Rezapur-Shahkolai, F., Hamzeh, B., Roshanaei, G., \& Babamiri, M. (2019). Aggression and its predictors among elementary students. Journal of Injury and Violence Research, 11(2), 159-170. doi:10.5249/jivr.v11i2.1102

Shrout, P. E., \& Bolger, N. (2002). Mediation in experimental and nonexperimental studies: New procedures and recommendations. Psychological Methods, 7(4), 422-445. doi:10.1037/1082-989X.7.4.422

Sullivan, A. D., Forehand, R., Vreeland, A., \& Compas, B. E. (2021). Does parenting explain the link between cumulative SES risk and child problems in the context of parental depression?. Child Psychiatry \& Human Development, 1-12. doi:10.1007/s10578-021-01130-9

Tremblay, R. E. (2004). Decade of behavior distinguished lecture: Development of physical aggression during infancy. Infant Mental Health Journal, 25(5), 399-407. doi:10.1002/ imhj.20015

Vandenberg, R. J., \& Lance, C. E. (2000). A review and synthesis of the measurement invariance literature: Suggestions, practices, and recommendations for organizational research. Organizational Research Methods, 3(1), 4-70. doi:10.1177/109442810031002

Wang, M., \& Liu, L. (2018). Reciprocal relations between harsh discipline and children's externalizing behavior in China: A 5-year longitudinal study. Child Development, 89(1), 174187. doi: $10.1111 /$ cdev. 12724

\section{In Korean}

Cho, B., Lee, J., Lee, H., \& Kwon, H. (1999). Dimensions and assessment of Korean parenting style. Journal of the Korean Home Economics Association, 37(10), 123-133.

Jeong, K., \& Park, C. (2017). Exploring viewpoints of transition to elementary school. Journal of Curriculum Integration, 11(4), 121-143.

Kim, I. S, Kim, Y. J, \& Kim. Y. H. (2010). The effects of attachment to the mother, mother's parenting style $\&$ young children's emotional regulation on aggression. The 
journal of Educational Studies, 41(3), 175-202.

Kim, K. H., \& Kang, H. K. (1997). Development of the parenting stress scale. Journal of the Korean Home Economics Association, 35(5), 141-150.

Lim, S. A. (2015). Effects of child maltreatment on delinquency by the mediation role of psychosocial adaptation -moderating effect of family income-. The Korean Society Of Child Welfare, 50, 85-108.

Oh, K. J., \& Kim, Y. A. (2009). Child Behavior Checklist for Ages 1.5-5. Seoul: Huno.

Oh, K. J., Kim, Y. A., Ha, E. H., Lee, H. L., \& Hong, K. E. (2010). Child Behavior Checklist for Ages 6-18. Seoul: Huno.

Shin, Y. (2012). A Longitudinal study on the developmental relationship between preschoolers' relational aggression and peer rejection using the autoregressive cross-lagged model. Korean Journal of Early Childhood Education, 32(3), 101115.

\section{ORCID}

Taehee Youn

http://orcid.org/0000-0002-3637-8836

Received November 1, 2021

Revision received November 1, 2021

Accepted December 5, 2021 